\title{
Economic Factors and Performance Measurement of Regional Governments in Sumatra and Java
}

\author{
Hurian Kamela ${ }^{1}$, Ryan Saputra Alam ${ }^{2}$ \\ ${ }^{1}$ Faculty of Economic and Business, Accounting, Universitas Indonesia, Margonda, Depok, Indonesia \\ ${ }^{2}$ Faculty of Economic and Business, Human Resources Management, Universitas Indonesia, Jakarta, \\ Indonesia \\ melakame193@gmail.com, rysalamilmi@gmail.com
}

\begin{abstract}
One measurement of performance in local government is the regional government performance score (EKPPD). The purpose of this study was to analyze the influence of economic factors with performance scores in local government. This study conducted 119 cities and regencies in Java and Sumatra for 2 years, 2015-2016. The total sample is 238 cities and districts. The reason for this sample was chosen because Java and Sumatra are two large islands in Indonesia and have quite high economic development. The research method used is regression using panel data. The dependent variable used is the performance score from the Regional Government. The independent variable used is economic factors such as the Human Development Index (HDI). Control variables are Poverty Rate and GINI Coefficient. The results of this study explain that HDI and GINI have a positive effect on the performance of local governments. The contribution of this study provides an explanation that the higher the poverty rate inherent with the better quality of life of the community, prove that developments in the City / Regency in the Regional Government have been implemented by the Regional Government following the capacity of the Regional Government.
\end{abstract}

Keywords: Performance; Regions; Economy; Government; HDI; Poverty; GINI

\section{INTRODUCTION}

The rules regarding regional autonomy have been regulated by the Government in the Law. Darumurti and Rauta (2000: 49) explain that the implementation of functions given by the Central Government to the Regional Government which is broader can create a burden regarding the readiness of the region in its implementation because the functions of the Regional Government are becoming wider to the City / Regency. In addition, regional autonomy provides flexibility to regional governments in carrying out their duties but remains transparent. Regional autonomy as an implementation that gives 
authority in making decisions that are getting better, can increase resources in accordance with needs, determine priorities, and develop the potential of the region to the fullest. The existence of regional autonomy must also be accountable to the community because there must be a decentralized system that reflects transparency effectively and efficiently (appropriate and properly).

In the implementation of good governance activities, it means that the implementation of regional financial management has been optimal, which can be reflected in the realization of the agency theory implementation. Jensen \& Meckling (1979) explained that agency theory in companies could be in the form of principals and agents, in government the position can be seen as an agent (Regional Government) and principal (community) giving political power to parties who have been delegated and chosen by the people.

The form of accountability of the Regional Government is reflected both as the demands of the community because the Regional Government is directly elected by the community. One of the tools in achieving this is a performance measurement that illustrates the changes in each year, whether it is increasing or not as a consequence of the implementation of the responsibilities that must be carried out by the Regional Government. 3 aspects must be considered carefully by the Regional Government along with increased responsibilities, namely (1) human resources, (2) financial resources, (3) involvement of facilities and infrastructure. Improved implementation of development in its activities can be from the development of its community, one of which is about the quality of its people, such as regarding human development, this reflects the magnitude of the problems that can be done by the Regional Government to overcome problems in society. Problems related to the quality of the community related to the community economy among them are poverty, the number of unemployed people, illiteracy, and food management. The thing that varies is that the planning carried out by the government can be successful or not. The implementation used by the Regional Government in its activities must be measured and systematic, which is reflected in the implementation of the performance of the Regional Government. Local governments use the Regional Budget and Budget (APBD) in financing their regional needs and development that has been approved by the Regional House of Representatives (DPRD) in meeting its utilization, both the budget and revenue budget. The economic factor is 
one part that can explain the performance of the City / Regency because the economic factor reflects the welfare of the community and the policies that have been carried out by the Government have been performed well.

This can be related to the performance that occurs in the Regional Government regarding the implementation of the Regional Revenue and Expenditure Budget (APBD), the attached performance score is a reflection of the results of resource management carried out by the Regional Government. Regional Governments must further improve the welfare of the community, especially in minimizing poverty rates. The lower the capacity and ability of financial management that is not mark good in regional development will create a negative effect, namely the lower public services provided by the Regional Government. Local governments are deemed unable to solve problems in improving their performance. The Government's performance was used in discussing public welfare, namely the performance score. Performance Score, namely the Evaluation of the Performance of Local Government Organizations (EKPPD), which reflects as a tool for the accountability of the Regional Government to the Central Government. Measurements in Local Government performance can be reflected in the scores officially released by the Ministry of the Home Affairs, since they reflect accountability.

Optimal government performance reflects the success of regional autonomy in preparing and regulating its regions following the Law. The requirements in implementing good regional autonomy according to (Syamsi, 1986: 99) there are 3 parts: (1) Regarding the ability of the organizational structure, namely the Regional Government can carry out all its activities and tasks in accordance with the burden and responsibilities. (2) Regarding the ability of the apparatus in the Regional Government that is must be able to carry out tasks in regulating and carrying out its activities, such as reflection on morals and discipline, (3) Regarding the ability of the region to participate in the society that is to play a role in encouraging the community to carry out development activities. At this third point, the role of performance is related to the role of the central government in encouraging communities in development activities.

Another recent study by Moric \& Šakovi (2020) which measures between performance and economy in 24 European countries, the result is that economic activity is related to performance, in accordance with the process of adopting activities related to progress at 
the economic level so that it is getting better, namely productivity. He et.al (2020) in China who discussed performance explained that economic factors influence performance such as tax burden and financial infrastructure. These two things made it clear that the role of the economy in governance is very strong, especially for local governments. Good development programs reflect implementation in realizing good governance (good governance). To make this happen, it is necessary to have institutional reforms and reforms on public sector management (Mardiasmo, 2002). Based on the link between performance and economic factors, the researchers will conduct a study entitled "Economic Factors and Performance Measurement of Regional Governments in Sumatra and Java in 2016-2017. The performance of the Regional Government used is the score of the Regional Government as well as for the independent variable and its control in the form of economic factors consisting of the Human Development Index (HDI), poverty rate, and the GINI coefficient.

The difference between this study and previous research is that this study will use a larger sample of cities and regencies in Java and Sumatra, because these two islands are islands that are more economically advanced compared to other islands in Indonesia. The contribution of this study provides an explanation that the higher the poverty rate, the better quality of life of the community and prove that developments in the City / Regency in the Regional Government have been implemented by the Local Government following the capacity of the Regional Government.

\section{LITERATURE}

Previous research based on research by Fenwick (2012) in the UK regarding performance scores, politics, and types of government in the UK, this study compared government performance scores with these factors. Other research in Indonesia which is adjusted to Harliyani \& Haryadi (2016) research on performance and Human Development Index (HDI) in Jambi Province, is different from this research since it will use a wider sample of cities and regencies in Java and Sumatra and add variables economy for performance comparison. This research is also based on previous research, Indra Tama (2015), which discusses financial performance before and after the application of the Act. The latest research on economic conditions also conducted by Presse \& Nov (2020) regarding the economic impact on governance in Ghana can be 
overcome and built when the government can be phased out of a government crisis by using the strategy of choice of destination for Foreign Direct Investments (FDI) in West Africa, local government to improve performance and economy based on appropriate policies in the country.

\section{Local Government Performance}

Performance measurement is useful in carrying out an analysis of public sector organization activities. As a result, performance indicators must be implemented such as service costs, usage, quality, service standards, services, and satisfaction.

Schiuma (2010) conducted research on how performance measurement systems in public organizations. The results provide stages regarding performance in government on Italy, the results of this study are that the implementation of performance was still dependent on the government, because of the limited implementation and implementation so that there are still shortages concerning performance.

\section{Human Development Index (HDI)}

Human Development Index (HDI) is one component of welfare measurement. These closely related to the role of regional autonomy, namely the achievement of human development goals that nearly related to how the role and commitment of the government could support the community so that they are more advanced and more developed. Research in Indonesia on the Human Development Index (HDI) and performance was developed from Harliyani \& Haryadi (2016) research in Jambi Province, the results of the research provide information that HDI influences performance.

\section{Poverty Rate}

Poverty explains the economic inability to meet the basic, which comes from clothing, food, and shelter (Alit and Sudiana, 2013). The number of poor people reflects how much the poor population inhabits a certain region. These were discussed by Wirawan (2015) that the population of Bali has high economic development, but there are still problems, one of which is the great number of people with poverty. This must be considered by the government because almost the majority of cities and regencies in 
Indonesia have the main problems (1) high number of unemployment, (2) high number of people with poverty.

\section{GINI Coefficient}

The control variable taken according Suparno's research (2016) in Kupang City which discusses the need for the GINI ratio to find out economic conditions, especially the differences between the rich and poor. GINI ratio is a measurement of evenness by comparing the diagonal area and the Lorenz curve (A) divided by the area of the triangle below the diagonal. Scores regarding the GINI ratio are in the range of 0 and 1 , namely: (1) <0.3 explains that inequality that occurs in an area is low, (3)>0.5 explains that inequality that occurs in an area is moderate, explains that inequality that occurs in an area is high. This score can be calculated manually or using data already available at the Central Statistics Agency (BPS). This variable describe the economic condition so that it was considered related to performance on local government.

Harliyani \& Haryadi (2016) explained that there is a link between HDI and performance in Jambi Province, decribes that the amount of effective human development improves the quality of performance, because the increasing quality of society will improve regional progress, thus performance is getting better. Dudzevičiūtė (2018) explains that poverty and inequality are related to economic growth. Poor people's problems including weak funding and low consumption of expenditure, resulting in aggregate demand decreases. From these two things, if it is related to performance measurement, one of the improvements in performance is related to good and accountable budget management.

The hypotheses in this study are:

\section{H1: HDI has a positive effect on performance.}




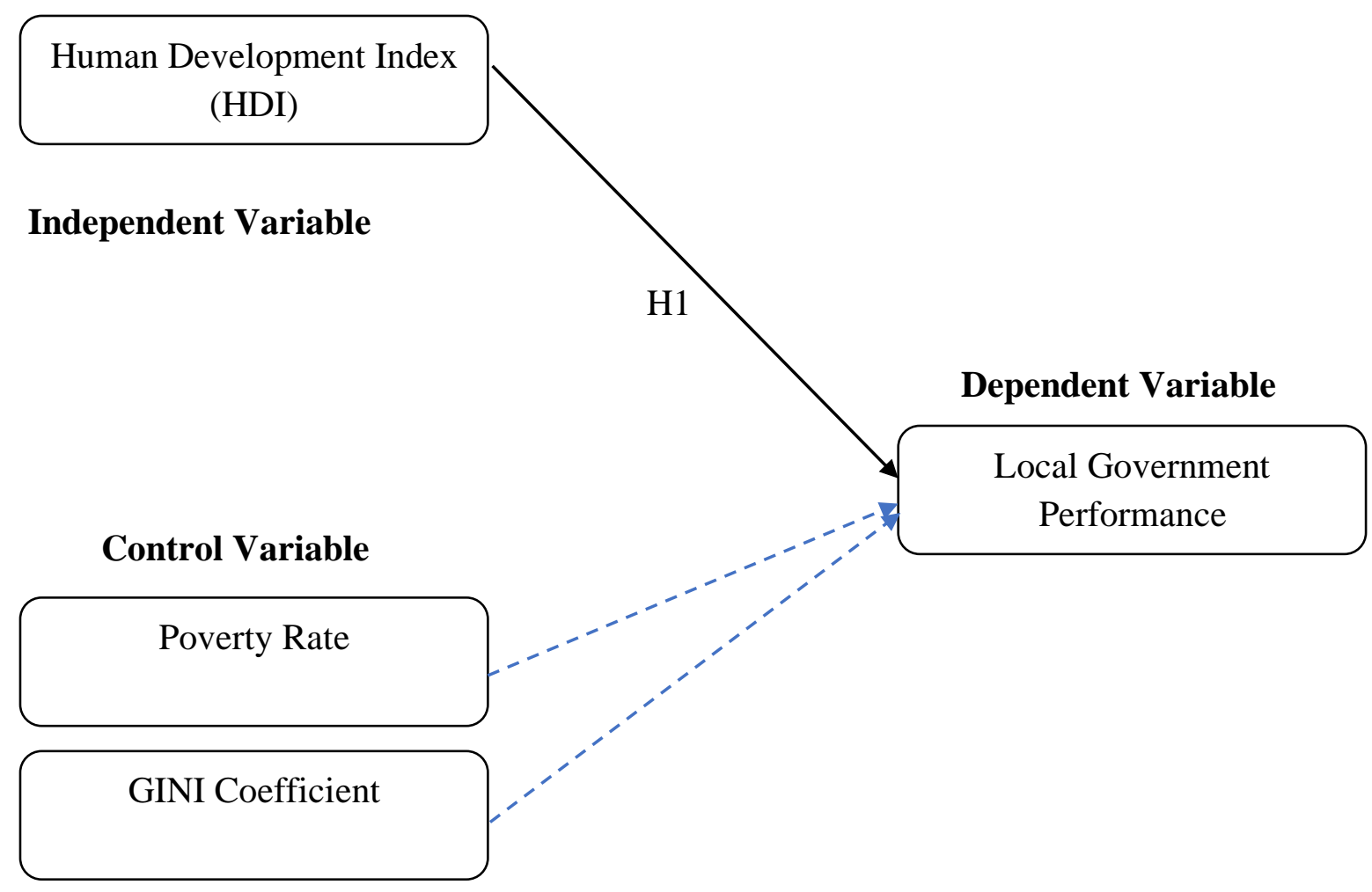

\section{METHODOLOGY}

The method used is panel regression. The data used in this study based on cities/regencies in Sumatra and Java Island as many as 119 samples for 2 years. The total number of observations is 238 cities/regencies. Data processing by Stata application from Version 14 using multiple linear regression method. Data collection techniques based on secondary data (secondary data) taken from the Ministry of Home Affairs and the Central Statistics Agency (BPS). For more details, see tables 1 and 2 regarding the data and measurements of this study:

Table 1. Data

\begin{tabular}{lc}
\hline Information & Observation \\
\hline Time Period & 2 years \\
Sample & 119 \\
Total Observation & 238 \\
\hline
\end{tabular}


Table 2. Measurement

\begin{tabular}{ccc}
\hline Variable & Observation & Formula \\
\hline PRF & Performance Measurement & Kemendagri (EKPPD Performance \\
HDI & Score & Score) \\
POV & Population Of Poverty & $\sqrt[a]{\text { I healthy } x \text { I education } x \text { I outputx } 100 \%}$ \\
GINI & GINI Coefficient & Populasi kemiskinan \\
& & $G R=1-\sum_{i=1}^{n}$ fpix $(F c i+F c i-1)$ \\
\hline
\end{tabular}

Source: Data processed, 2020

Therefore, the research formulation is:

$$
. \text { PRFit }=\text { HDIit }+ \text { POVit }+ \text { GINIit }+ \text { sit }
$$

Information:

PRF: Performance Measurement (Local Government Score)

HDI: Human Development Index

POV: Poverty Rate

GINI: GINI Score

\section{RESULT AND DISCUSSION}

Tabel 3. Statistic Descriptive

\begin{tabular}{cccccc}
\hline Variabel & N & Mean & Dev Std & Min & Max \\
\hline PRF & 238 & 3.051205 & .3307482 & 1.443 & 3.5926 \\
HDI & 238 & 69.64055 & 5.238518 & 58.18 & 81.58 \\
POV & 238 & 82917.82 & 89374.37 & 1340 & 490800 \\
GINI & 238 & .3335508 & .0451922 & .2136 & .49
\end{tabular}

Source: Data processed, 2020

Table 3 explains the descriptive statistics of the study. The PRF score (the measurement of performance scores) from the Regional Government (average 3.05) and the highest score / maximum score is 3.5926. HDI explains the Human Development Index to determine the quality of life in the City/Regency. Sampang Regency has the minimum HDI index (58.18) and Padang Kota with the maximum HDI index (81.58). The average poverty population is 82917 people and the minimum GINI score is $21.36 \%$ and a maximum score of $49 \%$. 
Tabel 4. Result

\begin{tabular}{|c|c|c|c|c|c|}
\hline Variable & & Coef & t-stat & Prob & Sign. \\
\hline Cons & & -6.573815 & -2.86 & 0.000 & $* *$ \\
\hline HDI & $(+)$ & .1419322 & 4.45 & 0.000 & $* * *$ \\
\hline POV & & $-7.28 \mathrm{e}-07$ & -4.54 & 0.436 & \\
\hline GINI & & .5961992 & -0.78 & 0.005 & \\
\hline
\end{tabular}

Table 4 explains the results of the study that Hypothesis 1 was accepted. HDI has a probability value of 0.000 this means that hypothesis 1 is accepted. This is consistent with Harliyani \& Haryadi (2016) research in Jambi that HDI affects financial performance. In this research, it is proven that the higher the HDI, the better the quality of the community reflects, the better the local government performance score. Cities and regencies that have high scores are qualified cities/regencies because of life expectancy, the standard of living, and adequate education. These happened due to the fact that most cities and regencies in Sumatra are quite advanced compared to other islands, although there are still several districts that have low scores.

The control variable, POV (poverty), has a probability value of 0.436 . This describes that higher poverty does not increase performance by the government. This explains that poverty may illustrate the high amount of poverty that will force the local governments to increase their programs, especially in developing effective human resources. However, when poverty rises, the Regional Government will face problems in carrying out activities related to the community, which can be caused by the limited funds owned by the Regional Government. For example, such as the amount of the Regional Budget (APBD) which are different in each City/Regency. The GINI variable gives a significant result because it has a probability value of 0.005 , this provides evidence that the higher GINI coefficient illustrates income distribution that reflects the least income inequality that occurs in the City/District distribution.

\section{CONCLUSION}

This research provides evidence that in Java and Sumatra Island reflects that not all economic factors related to government financial performance. The results obtained include (1) the Human Development Index (HDI) having a positive effect on 
performance, this can be caused by HDI using benchmarks that are appropriate to the development of society, especially the components of life expectancy and education. (2) Poverty (POV) does not affect performance, this can be caused by the limited funding of the Regional Budget (APBD) that does not have any effect on the community classified as less wealthy (3) GINI affects performance because the GINI score illustrates the equal distribution of income in Java and Sumatra.

This resulting study provides new findings that cities/regencies in Sumatra and Java have experienced quite effective equality from local governments, especially in the management of the Regional Budget (APBD) that has been carried out following their functions so that economic growth is getting better with evidenced by the increasing HDI regional development has largely been carried out under applicable laws. The limitation of this study is that it only uses a small portion of economic variables and a limited sample, this could be developed by adding other cities/regencies throughout Indonesia, as well as additional variables in the Local Government Financial Report (LKPD) such as budget and others.

\section{REFERENCES}

Alit, Wiradyatmika A.A. Gde dan Ketut Sudiana. (2013). Pengaruh Jumlah Penduduk, Jumlah Penyerapan Tenaga Kerja dan Pengangguran Terhadap Jumlah Penduduk Miskin di Kabupaten Buleleng. Jurnal Ekonomi Pembangunan, Fakultas Ekonomi dan Bisnis Universitas Udayana.

Darumurti, K.D dan Rauta. Umbu. (2000). Otonomi Daerah, Kemarin, Hari ini, dan Esok, Kritis, Vol. XII, No. 3, 1 - 53.

Dudzevičiūtè (2018). INVESTIGATION OF THE ECONOMIC GROWTH, POVERTY AND INEQUALITY INTER-LINKAGES IN THE EUROPEAN UNION COUNTRIES. JOURNAL OF SECURITY AND SUSTAINABILITY ISSUES ISSN 2029-7017 print/ISSN 2029-7025 online 2018 June Volume 7 Number 4 https://doi.org/10.9770/jssi.2018.7.4(19)

Fenwick \& Miller K. J. (2012). Political management and local performance : a testing relationship ? https://doi.org/10.1108/09513551211224261 
Harliyani \& Haryadi (2016). Pengaruh Kinerja Keuangan Pemerintah Daerah Terhadap Indeks Pembangunan Manusia di Provinsi Jambi. Jurnal Perspektif Pembiayaan dan Pembangunan Daerah Vol. 3 No. 3, Januari-Maret 2016 ISSN: 2338-4603 (print); 2355-8520 (online). Universitas Jambi.

He, F., Miao, X., Wong, C. W. Y., \& Tang, Y. (2020). Corporate Social Responsibility and Operating Performance : The Role of Local Character in Emerging Economies. https://doi.org/10.3390/su12124874

Jensen, M. and Meckling, W., (1976) . "Theory of the Firm: Managerial Behavior, Agency Cost and Ownership Structure." Journal of Financial Economics (305$360)$.

Mardiasmo. (2002). Otonomi dan Manajemen Keuangan Daerah. Andi, Yogyakarta

Moric, I., \& Šakovi, J. (2020). The Effect of Phases of the Adoption of the Circular Economy on Firm Performance : Evidence from 28 EU Countries, 1-13. https://doi.org/10.3390/su12062557

Presse, A. De, Apanews, A., \& Nov, D. D. (2020). Ghana's Vice President scores performance of economy high, 2020-2021. SyndiGate Media Inc.United States, Dakar.

Suparno (2016). KAJIAN GINI RATIO KOTA KUPANG. JEB 17. Jurnal Ekonomi \& Bisnis, Hal 1 - 10. Volume 1, Nomor 1, Maret 2016. Fakultas Ekonomi Universitas 17 Agustus 1945 Surabaya.

Wirawan \& Arka (2013). ANALISIS PENGARUH PENDIDIKAN PDRB PER KAPITA DAN TINGKAT PENGANGGURAN TERHADAP JUMLAH PENDUDUK MISKIN PROVINSI BALI. E-Jurnal EP Unud, 4 [5] :546-560 ISSN: 2303-0178. Universitas Udayana (UNUD). 